\title{
Cytopenia associated with iron deficiency anemia and iron therapy: A report of two cases
}

\section{Demir eksikliği anemisi ve demir tedavisi ile ilişkili sitopeni: Iki olgu sunumu}

\author{
Nihal Özdemir, Tiraje Celkan, Rejin Kebudi, Meltem Bor, İnci Yıldız \\ Department of Pediatric Hematology, Cerrahpaşa Faculty of Medicine, Istanbul University, Istanbul, Turkey
}

\section{To the editor,}

Thrombocytopenia before and after iron therapy has been reported in children with severe iron deficiency anemia (IDA), but the association and mechanism of action are not well established [1-6]. Herein we present 2 children with IDA that had low platelet and leukocyte counts at presentation $(n=1)$ and following oral iron therapy $(n=1)$. Written informed consent was obtained from the patient.

\section{Case 1}

A 7-year-old boy with pica presented with a diagnosis of leukemia. He did not have hepatosplenomegaly, lymphadenopathy, or infection. Laboratory results were as follows: hemoglobin (Hb): $6.9 \mathrm{~g} / \mathrm{dL}$; mean corpuscular volume (MCV): $66 \mathrm{fL}$; red cell distribution width (RDW): 20.3\%. Iron studies results were consistent with iron deficiency, as follows: serum iron: $13 \mu \mathrm{g} / \mathrm{dL}$; total iron binding capacity: 416 $\mu \mathrm{g} / \mathrm{dL}$; ferritin level: $10 \mathrm{ng} / \mathrm{mL}$. The patient's white blood cell (WBC) count was $2.9 \times 10^{3} / \mu \mathrm{L}\left(1.5 \times 10^{3} / \mu \mathrm{L}\right.$ neutrophils) and platelet count was $28 \times 10^{3} / \mu \mathrm{L}$. Bone marrow aspiration showed a normal number of megakaryocytes, low-level stored iron, and no blasts.
The patient was diagnosed as IDA. On d 5 of iron treatment the patient's findings were as follows: $\mathrm{Hb}$ : $7.4 \mathrm{~g} / \mathrm{dL}$; MCV: $68 \mathrm{fL}$; RDW: 25.7\%; WBC: $5.6 \times 10^{3} / \mu \mathrm{L}$; platelet count: $430 \times 10^{3} / \mu \mathrm{L}$.

\section{Case 2}

A 2-year-old boy presented with fatigue, pallor, diminished appetite, and irritability. Laboratory results were as follows: $\mathrm{Hb}: 5.3 \mathrm{~g} / \mathrm{dL}$; MCV: $54.5 \mathrm{fL}$; RDW: $32.5 \%$; WBC: $8.4 \times 10^{3} / \mu \mathrm{L}$; and platelet count: $769 \times 10^{3} / \mu \mathrm{L}$. Iron study results were as follows: serum iron: $7 \mu \mathrm{g} / \mathrm{dL}$; total iron binding capacity: 423 $\mu \mathrm{g} / \mathrm{dL}$; ferritin level: $1.8 \mathrm{ng} / \mathrm{mL}$. On d 6 of iron treatment there was a sudden decrease in his platelet count $\left(31 \times 10^{3} / \mu \mathrm{L}\right)$, but he had no signs of infection and viral serology was negative. Bone marrow aspiration showed a normal number of megakaryocytes, low-level stored iron, and no blasts. After iron therapy his platelet count was $194 \times 10^{3} / \mu \mathrm{L}$ on $\mathrm{d} 10$, and $382 \times 10^{3} / \mu \mathrm{L}$ on $\mathrm{d} 12$.

\section{Discussion}

Thrombocytopenia is an uncommon manifestation of iron deficiency (2\% of IDA patients) [7]. 
Perlman et al. reported 6 children with IDA and thrombocytopenia with a mean platelet count of $64 \times 10^{9} / \mathrm{L}$. After initiation of oral iron therapy the patients had rapid increases in their platelet counts. The researchers speculated that iron-dependent processes critical to thrombopoiesis were altered [3].

The mechanism of thrombocytopenia in iron deficiency might be an early response to direct stimulation of the EPO receptor on megakaryocytes or shunting into the erythroid precursors pathway, leading to decreased platelet formation [8]. Leukopenia may also occur in patients with IDA [3], though the exact mechanism is unclear; alteration in the activity of iron-dependent enzymes in leucopoiesis may be the cause. Animal experiments and in vitro studies have demonstrated that administration of erythropoietin down-regulated neutrophil production [9].

In conclusion, the 2 presented cases had a very common disease, but uncommon findings. IDA and iron therapy may be associated with decreased platelet and leucocyte counts.

\section{Conflict of interest statement}

The authors of this paper have no conflicts of interest, including specific financial interests, relationships, and/or affiliations relevant to the subject matter or materials included.

\section{References}

1. Lopas H, Rabiner SF. Thrombocytopenia associated with iron deficiency anemia. Clin Pediar 1966;5:609-16.

2. Berger M, Brass LF. Severe thrombocytopenia in iron deficiency anemia. Am J Hematol 1987;24:425-8.

3. Perlman MK, Schwab JG, Nachman JB, Rubin CM. Thrombocytopenia in children with severe iron deficiency anemia. J Pediatr Hematol Oncol 2002;24:380-4.

4. Go RS, Porrata LF, Call TG. Thrombocytopenia after iron dextran administration in a patient with severe iron deficiency anemia. Ann Intern Med 2000;132;925.

5. Ganti AK, Shonka NA, Haire WD. Pancytopenia due to iron deficiency worsened by iron infusion: a case report 2007;7;1:175.

6. Hurvitz H, Kerem E, Gross-Kieselstein E, Brand A, Branski D. et al. Pancytopenia caused by iron-dextran. Arch Dis Child 1986;61:194-6.

7. Kadikoylu G, Yavasoglu I, Bolaman Z, Senturk T. Platelet parameters in women with iron deficiency anemia. J Natl Med Assoc 2006;98:398-402.

8. McDonald TP, Clift RE, Cottrell MB. Large, chronic doses of erythropoietin cause thrombocytopenia in mice. Blood 1992,80:352-8.

9. Christensen RD, Liechty KW, Koenig JM, Schibler KR, Ohls RK. Administration of erythropoietin to newborn rats results in diminished neutrophil production. Blood 1991;78:1241-6. 